\title{
The Relationship Between the Length of Menstrual Period and Nutritional Status with the Incidence of Anemia
}

\author{
$1^{\text {st }}$ Rosi Kurnia Sugiharti \\ D3 Midwifery Study Program, \\ Faculty of Health Harapan Bangsa University, \\ Central Java, Indonesia \\ Rossy.kurnia@yahoo.com
}

\begin{abstract}
Abtract :In adolescence, many psychological and biological changes occur. One of the problems experienced by adolescents is anemia. Iron deficiency anemia can have a variety of effects on young women. One of them is affecting the immune system, and thus it is susceptible to illness, decreased activity, and low academic achievement. In general, the high prevalence of iron nutrition anemia is caused by several factors such as chronic blood loss, inadequate iron intake, inadequate absorption, and increased need for iron. The purpose of this study was to determine the relationship between the length of menstrual period and nutritional status with the incidence of anemia. Based on preliminary studies, 25 female students in Diploma III of Midwifery Study Program at Harapan Bangsa University were interviewed. It showed that students had severe anemia $(45 \%)$, moderate anemia $(40 \%)$, and mild anemia $(15 \%)$. The research design used was a correlation analysis research design with a cross-sectional approach. The sampling technique used was simple random sampling. The results showed that there was a relationship between the length of menstrual period and nutritional status with the incidence of anemia Keywords: length of menstrual period, nutritional status, incidence of anemia
\end{abstract}

\section{INTRODUCTION}

According to $\mathrm{WHO}$, adolescents are children reaching at the age of 10-18. In adolescence, there is a problem that occurs called anemia. Anemia in young women is still a problem of health if the prevalence is more than $15 \%$. [1] In general, the high prevalence of iron nutritional anemia is caused by several factors such as chronic blood loss, inadequate iron intake, inadequate absorption, and increased need for iron. Adolescent girls may suffer from anemia, this is understandable because adolescence is a period of growth that requires higher nutrients including iron. Besides, adolescents

\author{
$2^{\text {nd }}$ Etika Dewi Cahyaningrum \\ D3 Midwifery Study Program, \\ Faculty of Health Harapan Bangsa University, \\ Central Java, \\ Indonesia tita.etika@gmail.com
}

experience menstrual periods every month, thus they need higher iron. In this case, young women consume lower amount of food than men because they want to slim. Abstinence from certain foods and wrong eating habits are also causes of anemia in adolescent girls. [2]

Based on preliminary studies, 25 female students in Diploma III of Midwifery Study Program at Harapan Bangsa University were interviewed and it was found that students experienced severe anemia (45\%), moderate anemia $(40 \%)$, and mild anemia (15\%). From the problems above, the researchers are interested in conducting research on the relationship between the length of menstrual period and nutritional status with the incidence of anemia.

\section{METHODS}

The research method used was a correlation analysis research which evaluates a relationship between two variables in a situation or group of subjects. The research design used was crosssectional study. [3]

The population was all students of Diploma III of Midwifery Study Program at Harapan Bangsa University. The sampling technique used was simple random sampling. The total population was 82 female students. The Solvin's formula was performed to take the samples and it was obtained 50 female students.

Examining $\mathrm{Hb}$ (hemoglobin) of the samples was a technique of collecting data. After doing the $\mathrm{Hb}$ test, a research instrument was given to students. Data obtained from students was as the primary data.

In this study, the univariate analysis and bivariate analysis were also performed. The univariate analysis used was frequency distribution tables, while the bivariate analysis applied was the Chi-Square Test. 
III.RESULTS AND DISCUSSION

Table 1 Correlation betweeen Nutritional Status and the Incidence of Anemia

\begin{tabular}{|c|c|c|c|c|c|c|c|c|}
\hline & \multicolumn{4}{|c|}{ Anemia } & \multirow{2}{*}{\multicolumn{2}{|c|}{ Total }} & $P$ & \multirow[t]{3}{*}{$\alpha$} \\
\hline \multirow[t]{2}{*}{$\begin{array}{l}\text { Nutritional } \\
\text { Status }\end{array}$} & \multicolumn{2}{|c|}{ Anemia } & \multicolumn{2}{|c|}{$\begin{array}{c}\text { No } \\
\text { Anemia }\end{array}$} & & & \multirow[t]{2}{*}{$\begin{array}{c}\text { Valu } \\
e\end{array}$} & \\
\hline & $\mathrm{F}$ & $\%$ & $\mathrm{~F}$ & $\%$ & $\mathrm{~F}$ & $\%$ & & \\
\hline Underweight & 18 & 36 & 11 & 22 & 29 & 29 & 0,046 & 0.05 \\
\hline Normal & 27 & 54 & 20 & 40 & 47 & 47 & & \\
\hline Overweight & 5 & 10 & 19 & 38 & 24 & 54 & & \\
\hline
\end{tabular}

Based on table 1, it can be seen that most of the students who have anemia are students who have normal nutritional status as many as 27 people (54\%) and a small proportion of students who have overweight status are as many as 5 people $(10 \%)$. Of the students who did not have anemia, the majority of students who had normal nutritional status were 20 people (40\%), and a small proportion of students with underweight nutritional status were 11 people $(22 \%)$. Based on the Kolomogorv Smirnov test the resulting $\mathrm{p}$ value is 0.046 so it can be concluded that there is a relationship between nutritional status and anemia

Table 2 Correlation between Period of Menstruation and the Incidence Anemia

\begin{tabular}{|c|c|c|c|c|c|c|c|}
\hline \multirow{3}{*}{ Mom's } & \multicolumn{4}{|c|}{ Anemia } & \multicolumn{2}{|c|}{ Total } & \multirow{2}{*}{$\begin{array}{c}P \\
\text { Value }\end{array}$} \\
\hline & \multicolumn{2}{|c|}{ Anemia } & \multicolumn{2}{|c|}{$\begin{array}{c}\text { No } \\
\text { Anemia }\end{array}$} & & & \\
\hline & $\mathrm{F}$ & $\%$ & $\mathrm{~F}$ & $\%$ & F & $\%$ & 0,004 \\
\hline Normal & 13 & 26 & 27 & 54 & 40 & $\begin{array}{l}4 \\
0\end{array}$ & \\
\hline Abnormal & 37 & 74 & 23 & 46 & 60 & $\begin{array}{l}6 \\
0\end{array}$ & \\
\hline
\end{tabular}

Based on table 3 , it can be seen that most of the students who have anemia are students who have abnormal menstruation as many as 37 people (74\%) and a small proportion of students who have normal menstrual periods are as many as 13 people (26\%). Of the students who did not have anemia, the majority of students who had normal menstrual periods were 27 people (54\%), and a small proportion of students who menstruated were 23 people $(46 \%)$. Based on Chi Square, the resulting $\mathrm{p}$ value is 0.004 so it can be concluded that there is a relationship between menstruation and the incidence of anemia.

1. Relationship Between Nutritional Status and the Incidence of Anemia

The nutritional status of adolescent girls at the majority of universities is in the normal category, this is because respondents in this study respondents live with their parents so that their patterns and types of food are still guaranteed and can be arranged by their parents, as well as the respondent's residence near the market. causes respondent's parents to get food easily. There are several factors that can affect a person's nutritional status such as environmental, economic, socio-cultural, and biological or hereditary factors. [4]

The results of the study and in accordance with table 2 can be concluded that the majority of female students have menstrual periods and normal menstrual cycle lengths. this is because respondents in this study lived with their parents. The length and length of menstrual cycles that are not normal is one type of menstrual disorders, where menstrual disorders can be influenced by many things, such as food consumed and physical activity of hormonal and enzyme factors in the body, problems in vascular and genetic factors (heredity) [5]The results of indraini research, et al (2009) show the habit of consuming fruit and animal side dishes is positively related to the length of the menstrual process, where adolescents who consume a lot of animal side dishes and fruit will have more normal menstrual periods compared to adolescents who do not consume animal side dishes, and habits fruit consumption is negatively related to the normal length of the menstrual cycle, where more and more young women consume fruit, the distance between menstruation will be further from the normal length of the menstrual cycle. [6]

2. Relationship Between Period of Menstruation and the Incidence Anemia

This can occur because respondents who have abnormal menstrual periods will experience more blood loss during menstruation than respondents who have normal menstrual periods. [7] The length of the menstrual process will affect the number of red blood cells in the body, the longer the menstrual process, the more blood will come out, which can cause anemia problems in women. [8]The duration of menstruation in adolescents is strongly influenced by the condition of the adolescent's body, some conditions that can affect the duration of menstruation in adolescents such as fatigue due to dense activity and high stress. High stress can affect the hormones in the body and cause long periods. [9]

\section{IV.CONCLUSIONS}

There is a relationship between nutritional status and menstrual periods with the incidence of anemia.

\section{REFERENCES}

[1] Andira, Dita. 2012.Seluk Beluk Kesehatan Reproduksi Wanita: Jogjakarta:A Plus Books.

[2] Kusmiran, Eny. 2011. Kesehatan Reproduksi Remaja dan Wanita. Jakarta: Salemba Medika

[3] Notoatmodjo, S. 2010. Metodologi Penelitian Kesehatan. Jakarta: Rineka Cipta.

[4] Morgan \& Hamilton. 2009. Obstetri dan 
Ginekologi: Panduan Praktik, Edisi 2. Jakarta: EGC.

[5] Manuaba IBG. 2009. Memahami kesehatan reproduksi wanita Jakarta: EGC

[6] J. Corwin. 2009. Buku Saku Patofisiologi

[7] Widyastuti, Yani, dkk. 2009.Kesehatan Reproduksi. Yogyakarta: Fitramaya

[8] Reeder, Sharon. J, Martin, Leonide L, dan Griffin, Deborah Koniak. 2011. Keperawatan Maternitas: Kesehatan Wanita, Bayi dan Keluarga, Edisi 8. Jakarta: EGC.

[9] Perry \& Potter. 2009. Fundamental Keperawatan Edisi 7. Jakarta: Salemba Medik 